\title{
Uso de Inteligência Artificial para Avaliação da Qualidade do Leite
}

\author{
Laura B. Alves*, Elaine C. C. Poletti, Francisco J. Arnold \\ Universidade Estadual de Campinas - Faculdade de Tecnologia \\ 13484-332, Campus Limeira, Limeira, SP \\ E-mail: laurab.alves@gmail.com
}

\begin{abstract}
$\underline{\text { RESUMO }}$
O Brasil é um dos maiores produtores de leite no mundo, e a produção alcançou 32 bilhões de litros no ano de 2012 [4]. Do ponto de vista nutricional, o leite possui proteínas, gorduras, sais minerais e água, basicamente. Com toda importância econômica do setor leiteiro, é essencial a qualidade do leite, visto aqui como a conservação de sua integridade [9] [6]. O pagamento do leite geralmente é feito por litro e pela sua qualidade [5] e por esse motivo há diversos registros de adulterações em seu volume, como a adição de água, água oxigenada, e até mesmo sólidos como a ureia. Como forma de controle da qualidade do líquido, a análise do leite é feita por amostragem, usando métodos físico-químicos, os quais demandam tempo e apresentam custo elevado [7].

O objetivo deste trabalho é o desenvolvimento de um método de avaliação da qualidade do leite, de acordo com a relação dos índices de água e gordura, com uso de regras fuzzy e técnicas de ultrassom. Os índices de água e gordura se relacionam com a velocidade de propagação de ondas acústicas e com o coeficiente de atenuação do leite, os quais podem ser são obtidos a partir de uma técnica ultrassônica. Os valores dessas grandezas físicas se tornarão entradas em um sistema de base de regras fuzzy, o qual tem como saída o índice de aceitabilidade da amostra.

A técnica a ser utilizada emprega dois transdutores ultrassônicos (transmissor e receptor). $\mathrm{O}$ transmissor emite pulsos acústicos que são recebidos pelo receptor. Ambos encontram-se separados nas faces paralelas de um pequeno depósito que contem o leite a ser analisado. A velocidade de propagação da onda é dada pela relação entre a distância entre os transdutores (emissor e receptor) e o tempo que a onda leva para percorrê-la. Esta distância é conhecida e fixa, dado que os transdutores estão acoplados a um recipiente de acrílico.

O coeficiente de atenuação da onda é uma medida que indica a constante de decaimento exponencial da amplitude de uma onda plana em um meio homogêneo. Esta perda de energia da onda acústica pode ser originada por perdas intrínsecas [2], ligadas à dissipação da onda pela presença das partículas de gordura. As perdas causadas pelas partículas são proporcionais à concentração de gordura presente na amostra [6].

O BUA (Broadband Ultrasonic Attenuation) é um parâmetro de propagação muito utilizado, e é a expressão da taxa de atenuação em uma faixa de frequências demarcada. $O$ BUA de um material pode ser definido pela comparação do espectro de frequência do sinal ultrassônico de um material de referência na faixa de frequências desejada. Com a aplicação da FFT (Fast Fourier Transform), é possível aplicar a Equação 1 para encontrar o coeficiente como resultado da comparação entre os espectros de frequência do sinal de referência e do sinal analisado, que é uma região onde há uma relação aproximadamente linear (BUA).
\end{abstract}

$$
\alpha(f)=\left|20 \log _{10}\right| V_{r}(f)\left|-20 \log _{10}\right| V_{m}(f)||
$$

Onde:

- $V_{r}(f)$ : é o valor absoluto do espectro de frequência do sinal de referência;

- $V_{m}(f)$ : é o valor absoluto do espectro de frequência do sinal que se propagou no material. 
A metodologia para interpretação dos resultados é feita pela comparação entre uma referência (água) e a amostra de leite em teste, com regras inicialmente estabelecidas pela literatura [1][3][8].

Os dados capturados nos ensaios laboratoriais alimentam um sistema de base de regras fuzzy que possibilita a tomada de decisão. Como forma de discussão avalia-se o nível de aceitabilidade de amostra do produto (leite), desta forma as amostras analisadas podem ser classificadas como: Aceitável, Aceitável com Restrições ou Não Aceitável. A partir da saída do controlador e da classificação da amostra análises físico-químicas podem ser sugeridas para confirmação de resultado. Ou seja, o modelo definido caracteriza-se como uma ferramenta auxiliar de análise de qualidade do leite.

Embora não substitua as análises regulares físico-químicas, a validação do método via experimentos laboratoriais permitirá a confirmação da técnica como um modelo eficiente, móvel, de baixo custo e viável que beneficia o setor leiteiro, com destaque para o pequeno produtor e para o laticínio, de modo que análises possam ser realizadas instantaneamente e com maior frequência.

Palavras-chave: Qualidade do Leite, Modelagem, Lógica fuzzy, Ultrassom

\section{Referências}

[1] F. Bacaneli. "Determinação do teor de gordura no leite através de parâmetros acústicos", Dissertação de Mestrado, POLI-USP, 1998.

[2] D. A. Christensen. "Ultrasonic Bioinstrumentation". Harper \& Row, 1988.

[3] L. F Dorabiato. "Sistema de ultrassom para caracterização de leite bovino". Dissertação de Mestrado, UTPFR, 2007.

[4] Embrapa Gado de Leite, Panorama do Leite, no 77, Juiz de Fora - MG, (2013).

[5] F. H. Madalena. Valores econômicos para a seleção de gordura e proteína do leite. R. Bras. Zootec, vol. 29, (2000).

[6] C.A. Miles, D. Shore, and K.R. Langley. Attenuation of ultrasound in milks and creams. Ultrasonics, vol 28, pp $394-400$, (1990).

[7] Ministério da Agricultura, Pecuária e Abastecimento, Brasil. IN 62-2011, (2011).

[8] S. L. S. Nazario, et al . "Caracterização de leite bovino utilizando ultra-som e redes neurais artificiais". Sba Controle \& Automação, Natal, v. 20, n. 4, (2009).

[9] W. Pedricz, F. Gomide. "An introduction to fuzzy sets”. A Bradford Book, 1998.

[10] L. A. Zadeh. "Fuzzy Sets". Information and Control, 1965. 